\title{
PERKEMBANGAN KONDISI DEMOGRAFI DAN SOSIAL-EKONOMI DI KOTAMADYA YOGYAKARTA BESERTA IMPLIKASINYA UNTUK PENGEMBANGAN FASILITAS KOTA
}

\author{
Oleb: R. Rijanta
}

\begin{abstract}
This paper is addressing the demographic changes in Yogyakarta Municipality and its vicinity in order to identity their respective consequences on the planning of urban service facilities. Data employed in this paper are gathered from varions sources, mainly Population Censuses of 1980, 1990 and other documents. Popula. tion dynamics as detected from the development of various variables (size, density, bousebold size, structure, employment and education) in the last two decades give some rough ideas of the direction to which urban service facilities are to be developed. Some adjusments on the sectoral development strategies in the next decade are considered very urgen in order to aticipate the demographic consequences of the recent demographic changes.
\end{abstract}

\section{INTISARI}

Tulisan ini bertujuan menunjukkan perubaban demografis di Kotamadia Yogyakarta dan sekitarnya agar supaya dapat mengidentifikasi masing-masing konsekuensinya pada perencanaan fasilitas pelayanan. Data yang digunakan dalam tulisan ini berasal dari berbagai sumber, utamanya dari sensus penduduk tabun 1980, 1990 dan dokumen-dokumen lainnya. Dinamisasi penduduk dideteksi dari berbagai macam variabel perkembangan (ukuran, kepadatan, ukuran rumah tangga, struktur, pekerjaan dan pendidikan) pada dua dekade terakbir dimana dapat memberikan gagasan kasar dari arab dimana fasilitas-fasilitas pelayanan dikembangkan. Beberapa penyesuaian pada strategi-strategi pengembangan sektoral pada dekade berikutnya perlu dipertimbangkan sebagai sesuatu yang penting agar supaya dapat mengantisipasi dampak demografis dari perubahan demografis akbir-akbir ini.

\section{PENDAHULUAN}

Dalam dua dasawarsa terakhir ini Kotamadya Yogyakarta dan Daerah Istimewa Yogyakarta secara keseluruhan, mengalami perkembangan kependudukan yang sangat penting dan memiliki implikasi yang luas terhadap jenis dan jumlah kebutuhan fasilitas kota pa- 
da masa yang akan datang. Hal ini sangat jelas terlihat dari dinamika perkembangan jumlah, kepadatan, rerata jumlah anggota rumah tangga dan struktur demografi penduduk Kotamadya Yogyakarta. Paper ini bermaksud memberikan gambaran obyektif mengenai dinamika kependudukan yang berlangsing dilihat dari berbagai variabel serta menggali implikasinya terhadap arah perencanaan dan pengembangan berbagai jenis fasilitas kota.

Data yang digunakan untuk penulisan terutama bersumber dari hasil Sensus Penduduk 1980 dan 1990 yang menggunakan konsep dan definisi yang sama. Dengan demikian dapat dilakukan perhitungan- perhitungan laju pertumbuhan dengan tingkat akurasi yang memadai. Selain itu dengan konsep dan definisi operasional yang sama dapat diperbandingkan secara time seri perkembangan suatu variabel tertentu, sehingga memberikan kemungkinan dibuat suatu proyeksi ke depan.

Sensus Penduduk 1980 dan 1990 mencatat bahwa penduduk di satu dacrah pencacahan mencakup mereka yang sudah secara permanen tinggal di daerah itu, tamu yang sudah tinggal di daerah tersebut selamat 6 bulan atau lebih, mereka yang sedang bepergian kurang dari 6 bulan dan tanpa niatan menetap serta pendatang baru yang berniat menetap. Implikasi dari definisi ini adalah bahwa mereka yang termasuk dalam penduduk kota adalah orang-orang yang pada waktu 6 bulan terakhir sebelum pencacahan tinggal di Kotamadya Yogyakarta, ditambah mereka yang tinggal di kota ini kurang dari 6 bulan tetapi berniat menetap (Kantor Statistik Propinsi DrY, 1980). Jadi jumlah tersebut lebih kecil daripada jumlah orang yang setiap hari melaksa- nakan berbagai aktivitas dan memanfaatkan berbagai fasilitas dalam kota Yogyakarta yang mencakup juga para penglaju dan migran sirkuler. Meskipun demikian data ini masih dapat diterima sebagai dasar analisis daripada data registrasi yang memiliki lebih banyak keterbatasan baik pada aspek konsistensi internal maupun metodologi dalam pengumpulannya.

\section{Jumlah, Perkembangan dan Ke- padatan Penduduk}

Jumlah penduduk Kotamadya Yog. yakarta menurut hasil Sensus Penduduk 1990 yang lalu mencapai angka sebesar 412 ribu jiwa. Dibandingkan dengan jumlah yang tercatat pada tahun 1980 dapat dilihat adanya perkembangan sebesar 14 ribu jiwa, karena Sensus Penduduk 1980 hanya mencatat adanya 398 ribu jiwa. Perkembangan penduduk kota yang hanya sekitar 14 ribu jiwa selama 10 tahun ini memberikan angka laju pertumbuhan penduduk tahunan sebesar 0,34 pcrsen/. tahun.

Dibandingkan dengan perkembang. an penduduk daerah pinggiran kota, yang mencakup Kecamatan Banguntapan, Scwon, Kasihan, Gamping dan De. pok, terdapat perbedaan yang sangat menyolok. Dalam periode yang sama terdapat pertambahan penduduk sejumlah sekitar 110 ribu jiwa, yaitu 297 ribu pada tahun 1980 dan 398 ribu pada tahun 1990. Tabel 1 berikut memberikan gambaran lengkap mengenai perkembangan penduduk Kotamadya Yogyakarta dan daerah pinggirannya selama 10 tahun terakhir.

Dari tabel 1 dapat diamati juga bah. wa hanya lima dari 17 kecamatan di Kotamadya Yogyakarta yang mengalami pertumbuhan penduduk positif, se- 
mentara 12 kecamatan lainnya mengalami pertumbuhan penduduk negatif. Agihan keruangan kelima kecamatan yang masih mengalami laju pertumbuhan penduduk positif nampaknya berada di bagian paling pinggir dari wilayah Kotamadya Yogyakarta dan langsung berbatasan dengan kecamatan-kecamatan pinggiran. Kelima kecamatan tersebut adalah Mantrijeron berbatasan dengan Sewon, Wirobrajan dengan kasihan, Umbulharjo dan Kotagede dengan Banguntapan, serta-Tegalrejo dengan Kasihan dan Gamping. Zona-zona yang dibentuk oleh kecamatan-kecamatan yang saling berbatasan di atas merupakan daerah dengan laju per- tumbuhan penduduk tinggi, rata-rata di atas 2 persen/tahun, bahkan di beberapa tempat mencapai 3 persen/tahun.

Secara umum dapat dikemukakan bahwa kecamatan-kecamatan yang memiliki laju pertumbuhan penduduk tinggi adalah kecamatan-kecamatan dengan tingkat kepadatan penduduk yang relatif paling rendah, tetapi dengan kecenderungan meningkat secara pesat. Sementara itu kecamatan-kecamatan di pusat kota, sejumlah 12 kecamatan, secara absolut mengalami gejala sebaliknya, yaitu penurunan tingkat kepadatan penduduk.

Tabel 1. Jumlah, Pertumbuhan dan Kepadatan Pendudukan Kotamadya Yogyakarta dan Daerah Pinggiran Kota 1980 dan 1990

\begin{tabular}{|c|c|c|c|c|c|}
\hline \multirow{2}{*}{ Nama Kecamatan } & \multicolumn{2}{|c|}{$\begin{array}{c}\text { Jumlah } \\
\text { Penduduk }\end{array}$} & \multirow{2}{*}{$\begin{array}{c}\text { Pertumbuhan } \\
\text { Penduduk }\end{array}$} & \multicolumn{2}{|c|}{$\begin{array}{l}\text { Kepadatan } \\
\text { Penduduk }\end{array}$} \\
\hline & 1980 & 1990 & & 1980 & 1990 \\
\hline Banguntapan & 56335 & 71727 & 2,44 & 2171 & 2764 \\
\hline Sewon & 57820 & 69656 & 1,88 & 2143 & 2582 \\
\hline Kasihan & 51913 & 68683 & 2,84 & 1667 & 2205 \\
\hline Gamping & 48514 & 60192 & 2,18 & 1658 & 2243 \\
\hline Depok & 82661 & 128316 & 4,50 & 2325 & 4742 \\
\hline Jumlah (Pinggiran) & 297243 & 398574 & 2,97 & 2029 & 2721 \\
\hline Mantrijeron & 31560 & 32845 & 0,40 & 12233 & 12731 \\
\hline Wirobrajan & 25312 & 26975 & 0,64 & 14602 & 14986 \\
\hline Kraton & 26557 & 22807 & $\cdot 1,55$ & 19385 & 16647 \\
\hline Mergangsan & 32683 & 32188 & $\cdot 0,15$ & 14027 & 13815 \\
\hline Umbulharjo & 39823 & 58026 & 3,84 & 5254 & 7655 \\
\hline Kotagede & 16775 & 23297 & 3,34 & 4891 & 6792 \\
\hline Pakualaman & 14309 & 12181 & $-1,60$ & 22358 & 19033 \\
\hline Gondomanan & 20105 & 17659 & $-1,29$ & 17792 & 15627 \\
\hline Ngampilan & 22403 & 20494 & $-0,89$ & 26050 & 23830 \\
\hline Godongtengen & 26058 & 22825 & $-1,32$ & 26321 & 23056 \\
\hline Danurejan & 26246 & 23430 & $\cdot 1,13$ & 23860 & 21300 \\
\hline Gondokusuman & 57067 & 56561 & $.0,09$ & 14125 & 14000 \\
\hline Jetis & 32669 & 30603 & $-0,65$ & 18994 & 17792 \\
\hline Tegalrejo & 26624 & 32168 & 1,91 & 9087 & 10979 \\
\hline Jumlah (Kodya) & 398727 & 412059 & 0,34 & 12269 & 12678 \\
\hline
\end{tabular}

Sumber : Hasil SP 1990 dan Bappeda I DIY, 1992 


\section{Struktur Demografi}

Menurut umurnya penduduk Kotamadya Yogyakarta, scbagaimana pola umum Daerah Istimewa Yogyakarta, tclah menunjukkan pergeseran ke struktur yang makin menua. Ial ini ditandai dengan semakin membesarnya proporsi penduuduk usia produktif dan usia muda dan anak-anak. Tabel 2 berikut menunjukkan struktur umur dan jenis kelamin penduduk Kotamadya Yogyakarta.

Tabel 2. Komposisi Penduduk Kotamadya Yogyakarta Menurut Umur dan Jenis Kelamin 1984

\begin{tabular}{|c|c|c|c|}
\hline Kelompok Umur & Laki-laki & Pcrempuan & Total \\
\hline $0 \cdot 4$ & 19.495 & 17.754 & 37.247 \\
\hline $5 \cdot 9$ & 19.749 & 18.175 & 37.924 \\
\hline $10 \cdot 14$ & 21.528 & 20.018 & 41.546 \\
\hline $15 \cdot 19$ & 30.682 & 29.957 & 60.639 \\
\hline $20-24$ & 37.697 & 29.496 & 67.193 \\
\hline $25-29$ & 21.804 & 16.331 & 38.135 \\
\hline $30 \cdot 34$ & 10.213 & 9.498 & 19.711 \\
\hline $35 \cdot 39$ & 8.709 & 9.638 & 18.347 \\
\hline $40-44$ & 8.540 & 9.238 & 17.778 \\
\hline $45-49$ & 7.544 & 8.857 & 16.401 \\
\hline $50 \cdot 54$ & 8.031 & 8.917 & 16.948 \\
\hline $55 \cdot 59$ & 6.039 & 5.971 & 12.010 \\
\hline $60 \cdot 69$ & 4.408 & 5.471 & 9.879 \\
\hline $65 \cdot 69$ & 2.967 & 3.747 & 6.714 \\
\hline $70 \cdot 74$ & 2.161 & 3.266 & 5.427 \\
\hline $75+$ & 2.331 & 4.048 & 6.379 \\
\hline Jumlah & 211.898 & 200.382 & 412.280 \\
\hline
\end{tabular}

Sumber: Bappeda II Kodya Yogyakarla, 1984

Dari tabel di atas dapat diamati bahwa sekitar 75.000 dari 412.000 penduduk Kotamadya Yogyakarta jatuh dalam kategori anak- anak dan sekitar 18.000 jatuuh dalam kategori penduduk usia lanjut, sedangkan sebagian besar lainnya adalah kelompok penduduk usia produktif. Untuk data yang paling baru diperkirakan proporsi penduduk usia lanjut sudah semakin besar, demikian pula penduduk usia produktif. Namun kelompok anak-anak di- pastikan telah turun lagi jumlahnya sebagai dampak langsung keberhasilan program keluarga berencana.

Hasil perhitungan angka jenis kela. min di sebagian besar kecamatan di Kotamadya Yogyakarta menunjukkan angka di bawah 100. Artinya, sccara umum jumlah populasi penduduk perempuan lebih dominan daripada lakilaki. Angka yang paling rendah dicapai oleh Kecamatan Gonodomanan dan Pakualaman yang merupakan pusat ko- 
ta, yaitu sekitar 87 . Ini berarti dari setiap 214 penduduk akan dijumpai 100 penduduk laki-laki dan 114 penduduk perempuan. Interpretasi dari keadaan semacam ini ialah bahwa di pusat kota, populasi penduauk migran relatif lebih kecil daripada pinggiran, karena di pusat kota fasilitas akomodasi yang murah sudah tidak ada lagi schingga para migran yang kebanyakan miskin memilih akomodasinya di pinggirann kota*). Dengan demikian transportasi yang murah antara daerah pinggiran dan pusat kota sangat vitai kebcradaannya, agar para migran ini dapat mclaksanakan kcgiatan ekonominya.

Kehadiran penduduk migran di daerah pinggiran kota sangat jelas terbukti dari besarnya angka peningkatan rasio jenis keiamin dari tahun 19801990 di kecamatan-kecamatan Wirobrajan, Kotagede, Banguntapan, Sewon, Kasihan, Gamping dan Depok. Tabel 3 berikut menggambarkan variasi angka rasio jenis kelamin dan besarnya rata-rata jumlah anggota rumahtangga di Kotamadya Yogyakarta 1980 dan 1990.

Dari tabel tersebut dapat dikenali secara screntak rata-rata jumlah anggota rumah tangga di semua kecamatan mengalami penurunan antara 0,3-1,7 sclama 10 tahun. Implikasi dari semakin kecilnya rata-rata jumlah anggota rumahtangga itu adalah keperluan ruang untuk rumah secara teoritis dapat diperkecil sesuai standard. Namun demikian bila dilihat besarnya jumlah penduduk yang memerlukan rumah, maka secara keseluruhan kebutuhan akan ruang untuk pemukiman tetap besar. Langkah yang logis untuk pemecahan masalah ini ialah dengan melaksanakan relokasi ke luar kota seperti yang telah berjalan selama ini atau dengan memperkenalkan apartemen murah.

Tabel 3. Rasio Jenis Kelamin dan Jumlah Anggota Rumahtangga Rata-rata di Kotamadya Yogyakarta, 1980-1990 (\%).

\begin{tabular}{|c|c|c|c|c|c|c|}
\hline \multirow{2}{*}{ Nama Kecamatan } & \multicolumn{3}{|c|}{ Rasio Jenis Kelamin } & \multicolumn{3}{|c|}{ Household Size } \\
\hline & 1980 & 1990 & Beda & 1980 & 1990 & Beda \\
\hline Banguntapan & 95,6 & 100 & $+4,4$ & 4,7 & 4,3 & $-0,4$ \\
\hline Sewon & 97,1 & 98,5 & $+1,4$ & 4,7 & 4,0 & $-0,7$ \\
\hline Kasihan & 95,0 & 95,9 & $+0,9$ & 4,6 & 4,3 & $-0,3$ \\
\hline Gamping & 96,2 & 98,7 & $+2,5$ & 4,6 & 4,3 & $-0,3$ \\
\hline Depok & 108,7 & 112,5 & $+3,8$ & 4,6 & 2,9 & $-1,7$ \\
\hline Mantrijeron & 94 & 93,9 & $\begin{array}{r}3 \\
-\quad 0,1\end{array}$ & 5,1 & 4,5 & $-0,6$ \\
\hline Wirobrajan & 100 & $10 !, 6$ & $+1,6$ & 4,9 & 3,8 & $-1,1$ \\
\hline Kraton & 95 & 90,3 & - 4,7 & 4,9 & 4,3 & $.0,6$ \\
\hline Mergangsan & 103 & 96,4 & - 6,6 & 5,2 & 3,9 & $-1,3$ \\
\hline Umbulharjo & 105 & 99,1 & $\begin{array}{l}-5,9 \\
-\end{array}$ & 5,1 & 3,3 & $-1,8$ \\
\hline Kotagede & 97 & 98,5 & $+1,5$ & 4,6 & 4,2 & $-0,4$ \\
\hline Pakualaman & 95 & 87,6 & - 7,4 & 4,4 & 3,8 & $.0,6$ \\
\hline Gondomanan & 92 & 87,1 & $-4,9$ & 5,0 & 4,4 & $-0,6$ \\
\hline Ngampilan & 95 & 86,9 & $-8,1$ & 5,1 & 4,7 & $-0,4$ \\
\hline Gedongtengen & 95 & 91,4 & - 3,6 & 4,9 & 4,4 & $-0,5$ \\
\hline Danurejan & 104 & 98,9 & $-5,1$ & 5,0 & 3,9 & $-1,1$ \\
\hline Gondokusuman & 111 & 98,9 & $-12,1$ & 4,2 & 2,9 & $\cdot 1,3$ \\
\hline Jetis & 104 & 98,8 & $\begin{array}{r}-5,2 \\
\text { - }\end{array}$ & 4,3 & 3,8 & $-0,5$ \\
\hline Tegalrejo & 101 & 100,4 & $-0,6$ & $4,73,9$ & 3,9 & $-0,8$ \\
\hline
\end{tabular}

Sumber : Hasil SP 1980 dan Bappeda I DIY, 1992

*) Salab satu ciri penduduk imigran ialab angka sex rasio yang tinggi (> 100). 


\section{Struktur Pendidikan Penduduk}

Penduduk Kotamadya Yogyakarta dapat dikatakan memiliki tingkat pendidik yang sangat tinggi. Dari scjumlah 351770 penduduk berumur 10 tahun ke atas hanya tercatat 6,8 persen yang tidak/beium pernah sekolah dan sckitar 14,2 persen tidak/belum tamat SD. Proporsi mereka yang menamatkan SD saja sudah mencapai 21,9 persen, disusul sekitar 18 persen menamatkan SMTP dan hampir sepertiga tamat SMTA (32,3 persen). Lainnya, sckitar 15 persen menikmati pendidikan tinggi baik diploma maupun pendidikan di Universitas. Tabel berikut menyajikan tingkat pendidikan penduduk di Kotamadya Yogyakarta tahun 1990.

Tabel 4. Tingkat Pendidikan Penduduk Berumur 10 Tahun Ke Atas pada tahun $1990(\%)$

\begin{tabular}{|l|r|r|r|}
\hline Tingkat Pendidikan & Laki-laki & Perempuan & Laki $^{2}+$ Perempuan \\
\hline Tidak/belum pernah sekolah & 2,2 & 11,1 & 6,8 \\
Tidak tamat SD & 13,1 & 15,4 & 14,2 \\
SD & 19,8 & 22,1 & 20,9 \\
SMTP Umum & 18,0 & 15,9 & 16,9 \\
SMTP Kejuruan & 1,6 & 1,4 & 1,5 \\
SMTA Umum & 27,9 & 20,0 & 23,8 \\
SMTA Kejuruan & 8,5 & 8,4 & 8,5 \\
D1/D2 & 0,5 & 0,5 & 0,5 \\
D3 & 3,5 & 2,6 & 3,0 \\
Universitas & 4,8 & 2,7 & 3,7 \\
\hline Jumlah (\%) & 100 & 100 & 100 \\
Jumlah (N) & 171,534 & 180.236 & 351770 \\
\hline
\end{tabular}

Sumber: Hasil SP 1990

Tabel di atas sekaligus juga menunjukkan adanya perbedaan tingkat pendidik antara laki-laki dan perempun. Proporsi perempuan pada tingkat pendidikan tamat SD ke bawah nampak lebih dominan daripada laki-laki. Scbaliknya kclompok laki-laki pada umumnya memilik proporsi lebih besar pada kategori pendidikan SMTP ke atas. Pada tingkat pendidikan tertinggi (universitas) nampaknya perbedaan tersebut tidak hanya terjadi secara relatif juga secara absolut.

\section{Struktur Ekonomi}

Untuk melihat perkembangan struktur ekonomi Kotamadya Yogyakarta digunakan dua variabel utama, yaitu lapangan kerja penduduk dan PDRB. Ka. rena perbedaan tahun penumpulan data maka perhitungan tingkat produktivitas tenaga kerja per sektor tidak dapat dilakukan. Namun data produktivitas tenaga kerja total untuk lima tahun yang lalu sudah tersedia dan interpretasi dapat dilakukan. 
Secara keseluruhan struktur ekonomi Kotamadya Yogyakarta didominasi oleh peranan sektor jasa dan perdagangan baik dari penyerapan tenaga kerja maupun PDRB. Pada tahun 1990 yang lalu lebih dua pertiga angkatan kerja yang bekerja jatuh dalam sektor perdagangan dan jasa dengan kontri- busi berturut-turut sebesar 33,4 dan 38,6 persen. Sektor lain yang relatif penting kontribusinya adalah scktor industri pengolahan, yang proporsinya mencapai 12,9 persen. Tabel berikut menyajikan selengkapnya struktur pekerjaan di Kotamadya Yogyakarta Yog. yakarta pada tahun 1990 .

Tabel 5. Penduduk yang bekerja di Kotamadya Yogyakarta menurut lapangan kerja dan Jenis kelamin 1990 (\%)

\begin{tabular}{|l|r|r|r|}
\hline \multicolumn{1}{|c|}{ Lapangan Pekerjaan } & Laki-laki & Perempuan & Laki $^{2}+$ Perempuan \\
\hline Pertanian, berburuan, kehutanan & 1,5 & 0,7 & 1,1 \\
Pertambangan dan penggalian & 0,2 & 0,2 & 0,2 \\
Industri pengolahan & 14,9 & 10,3 & 12,9 \\
Listrik, gas dan air & 0,4 & 0,0 & 0,2 \\
Bangunan & 6,8 & 0,2 & 3,9 \\
Perdagangan besar, eceran, hotel & & & \\
dan rumah makan & 26,1 & 42,7 & 33,4 \\
Angkutan, pergudangan dan komu- & & & \\
nikasi & 8,9 & 0,6 & 5,2 \\
Keuangan, asuransi, sewa bangunan & 2,6 & 2,2 & 2,6 \\
Jasa kemasyarakatan & 0,1 & 0,1 & 0,1 \\
Lainnya & 0,1 & 0,1 & 0,1 \\
Tidak tahu & 1,3 & 1,9 & 1,6 \\
\hline Total (\%) & 100 & 100 & 100 \\
Total (N) & 86851 & 68097 & 154948 \\
\hline
\end{tabular}

Sumber : Hasil SP 1990

Tabel di atas juga menunjukkan bahwa banyak sektor-sektor yang kontribosinya masih kurang dari 10 persen. Perbedaan struktur lapangan kerja menurut jenis kelamin juga cukup jelas terlihat. Kelompok jenis kelamin perempuan nampak mendominasi sektorsektor perdagangan dan jasa. Sementara di sektor-sektor industri pengolahan, bangunan, angkutan dan keuangan lebih dominan partisipasi angkatan kerja laki-laki.

Dilihat dari PDRB tcrnyata sektor perdagangan dan jasa yang sangat dominan dalam mengakomodasikan tenaga kerja juga agak penting sumbungannya terhadap PDRB. Dari segi PDRB dominasi peranan sektor jasa tidak muncul, tetapi sektor perdagangan muncul dalam urutan pertama dengan 
sumbangan sekitar 27,76 persen. Scksor transportasi dan pemerintahan muncul pada tempat kedua dan ketiga masing-masing dengan 16,21 dan 14,57 persen. Scktor jasa, bersama-sama sektor industri pengolahan dan sewa rumah menyumbang antara 8-9 persen terhadap PDRB tahun 1987-1988.

Tabel 6 PDRB Kotamadya Yogyakarta menurut scktor 1987-1988

\begin{tabular}{|l|r|r|}
\hline \multicolumn{1}{|c|}{ Sektor Kegiatan } & 1987 & 1988 \\
\hline Petanian, berburuan, kehutanan \& perikanan & 2,47 & 2,48 \\
Pertambangan dan penggalian & 0,01 & 0,00 \\
Industri pengolahan & 10,01 & 8,34 \\
Listrik, gas dan air & 1,91 & 1,71 \\
Bangunan & 5,80 & 5,86 \\
Perdagangan & 27,19 & 27,76 \\
Angkutan, pergudangan dan komunikasi & 15,96 & 16,21 \\
Keuangan, asuransi, sewa bangunan & 6,41 & 5,84 \\
Sewa rumah & 9,09 & 9,08 \\
Pemerintahan dan Hankam & 13,15 & 14,57 \\
Jasa-jasa & 8,0 & 8,14 \\
Total (\%) & $(100)$ & $(100)$ \\
Total PDRB (Ribuan) & 224.096 .274 & 245.139 .518 \\
Penduduk tengah tahun & 434.876 & 449.620 \\
PDRB/Capita & 515.311 & 545.210 \\
\hline
\end{tabular}

Sumber : Kotamadya YogyakartaDalam Angka 1988

Distorsi posisi sektor perdagangan dalam mengakomodasi tenaga kerja dan dalam menyumbang PDRB memberikan indikasi adanya sektor kegiatan yang dapat dikategorikan sebagai sektor informal. Sektor informal di kota Yogyakarta ini sangat kuat asosiasinya dengan usaha-usaha kecil dan tradisional yang memiliki muatan ciri khas kota Yogyakarta. Namun di sisi lain dijumpai sektor perdagangan yang berskala besar, bahkan beroperasi sebagai perusahaan multinasional (seperti Mc. Donald, Kentucky Fried Chicken, Coca-cola) dan perusahaan-perusaha- an nasional yang lain. Diversitas struktur ekonomi kota yang demikian ini cenderung dapat diklasifikasikan secara dikotomis menjadi sektor formal dan informal. Dengan demikian untuk kepentingan pelestarian citra kota kedua sektor terscbut perlu diintegrasikan secara mutualistis.

\section{Implikasi Perkemabngan Demo- grafi terhadap arah pengembang- an fasilitas kota.}

Untuk merumuskan implikasi perkembangan demografi dalam pengembangan kota maka ditempuh prosedur 
Iisting temuan studi, interpretasi temuan dan akhirnya diidentifikasi implikasi dari setiap temuan pada beberapa sektor pengembangan kota yang mencakup transportasi, perdagangan, pariwisata, perumahan dan pendidikan. Hasil identifikasi berbagai implikasi perkembangan demografi dan sosial ekonomi di Yogyakarta selama dua dasawarsa terakhir disajikan selengkapnya pada tabel 7 berikut.

\section{Kesimpulan}

Analisis kondisi demografi dan sosial ekonomi berdasarkan hasil Sensus Penduduk dan data sekunder yang ada pada tingka7 administrasi Kotamadya dan propinsi hanya dapat memberikan indikasi awal tentang arah dan jenis fasilitas pelayanan kota yang diperlukan pada masa yang akan datang. Untuk sampai pada tingkat jumlah fasilitas pelayanan yang dibutuhkan masih dituntut adanya usaha menggali data tambahan terutama mengenai jumlah penghuni kota yang tidak tetap beserta kebutuhannya dalam kota. IIal ini sebenarnya merupakan wujud nyata dari perbedaan jumlah penghuni kota pada siang dan malam hari.

Pada siang hari kota sclain ditempati olch penduduknya juga menampung penghuni tidak permanen (penglaju) dengan berbagai kepentingannya. Baik penghuni non permanen maupun penduduk permanen dalam kota memerlukan pelayanan berbagai fasilitas kota. Selain itu perhatian perlu juga dicurahkan pada intensitas orang yang masuk dari luar kota hanya semata-mata untuk mencari pelayanan tertentu yang tidak ada di dacrah asalnya. Dengan demikian untuk perencanaan jumlah fasilitas pelayanan kota diperlukan informasi tambahan tentang jumlah dan perilaku tuntutan pelayanan dari para penglaju. Ini hanya dapat dilakukan melalui penelitian survai pada tingkat individu para penglaju.

\section{Daftar Pustaka}

Kantor Statistik Propinsi DIY, 1990. Hasil Sensus Penduduk 1990 Kabupaten Sleman. Yogyakarta: BPS

Kantor Statistik Propinsi DIY, 1990. Hasil Sensus Penduduk 1990 Kabupaten Bantul. Yogyakarta: BPS.

Kantor Statistik Propinsi DIY, 1990. Hasil Sensus Penduduk 1990 Kotamadya Yogyakarta. Yogyakarta: BPS.

Bappeda I DIY, 1992. Rencana Struktur Tata Ruang Propinsi Daerah Istimewa Yogyakarta. Yogyakarta: Bappeda I DIY - P4N UGM.

Bappeda II Kodya Yogyakarta, 1984. Kotamadya Yogyakarta Dalam Rangka 1984. Yogyakarta : Bappeda II Kodya Yogyakarta.

Bappeda II Kodya Yogyakarta, 1984. Kotamadya Yogyakarta Dalam Angka 1988. Yogyakarta : Bappeda II Kodya Yogyakarta. 
TABEL 7 TEMUAN STUDI, INTERPRETASI DAN IMPLIKASI SEKTORAL DARI ASPEK KEPENDUDUKAN

\begin{tabular}{|c|c|c|c|c|c|c|c|}
\hline \multirow{2}{*}{ No. } & \multirow{2}{*}{ TEMUAN STUDI } & \multirow{2}{*}{ INTERPRETASI } & \multicolumn{5}{|c|}{ IMPLIKASI SEKTORAL } \\
\hline & & & TRANSPORTASI & PERDAGANGAN & PARIWISATA & PERUMAHAN & PENDIDIKAN \\
\hline 1.' & $\begin{array}{l}\text { Penurunan jumlah } \\
\text { absolut, laju pertum- } \\
\text { buhan, penduduk, } \\
\text { household size, di } 12 \\
\text { kecamatan di pusat } \\
\text { kota. }\end{array}$ & $\begin{array}{l}\text { Terjadi banyak per- } \\
\text { ubahan fungsi ba- } \\
\text { ngunan dari tempat } \\
\text { tinggal menjadi tem- } \\
\text { pat usaha atau lahan } \\
\text { yan g dijadikan tem- } \\
\text { pat usaha }\end{array}$ & $\begin{array}{l}\text { Relevan: } \\
\text { Jenis, jumlah } \\
\text { dan arah angkut- } \\
\text { an internal antar } \\
\text { bagian dalam } \\
\text { kota perlu pena- } \\
\text { taan terutama } \\
\text { kualitas }\end{array}$ & $\begin{array}{l}\text { Relevan: } \\
\text { Penurunan volu- } \\
\text { me barang kon- } \\
\text { sumsi bagi pen- } \\
\text { duduk kota seka- } \\
\text { ligus angkutan } \\
\text { barang tersebut }\end{array}$ & $\begin{array}{l}\text { Relevan: } \\
\text { Konservasi bangunan } \\
\text { yang bernilai historis } \\
\text { dan dikembangkan } \\
\text { sebagai objek wisata }\end{array}$ & $\begin{array}{l}\text { Relevan: } \\
\text { Antisipasi ben- } \\
\text { tuk-bentuk peru- } \\
\text { mahan untuk ke- } \\
\text { luarga kecil di } \\
\text { pusat kota }\end{array}$ & $\begin{array}{l}\text { Relevan: } \\
\text { Menilai perlu-tidak- } \\
\text { nya relokasi fasilitas } \\
\text { pendidikan ke luar/- } \\
\text { pinggirkota }\end{array}$ \\
\hline 2. & $\begin{array}{l}\text { Pertumbuhan penìu- } \\
\text { duk tinggi di } 5 \text { keca- } \\
\text { matan paling pinggir } \\
\text { dan zona pinggiran } \\
\text { di Kabupaten Bantul } \\
\text { dan Sleman }\end{array}$ & $\begin{array}{l}\text { Zona ini mengako- } \\
\text { modasi migran dari } \\
\text { Kodia Yogyakara } \\
\text { maupun dari dacrah } \\
\text { lain untuk tempat } \\
\text { menetap yang leb:h } \\
\text { murah dan dalam zo- } \\
\text { na komutasi ke pusat } \\
\text { kota }\end{array}$ & $\begin{array}{l}\text { Relevan: } \\
\text { Jenis. jumlah } \\
\text { dan arah angkut- } \\
\text { an internal \& ek- } \\
\text { stemal antar ko- } \\
\text { ta dengan hinter- } \\
\text { land perlu pena- } \\
\text { taan: kualitas } \\
\text { kuantitas }\end{array}$ & $\begin{array}{l}\text { Relevan: } \\
\text { Peningkatan vo- } \\
\text { lume barang } \\
\text { konsumsi bagi } \\
\text { penduduk dan } \\
\text { volume angkut- } \\
\text { an barang terse- } \\
\text { but }\end{array}$ & $\begin{array}{l}\text { Relevan: } \\
\text { Penyediaan fasilitas } \\
\text { wisata kota dalam sa- } \\
\text { tu paket kunjungan } \\
\text { sehari bagi pelajar } \\
\text { dan anak-anak }\end{array}$ & $\begin{array}{l}\text { Relevan: } \\
\text { Optimasi pe- } \\
\text { manfaatan ruang } \\
\text { dengan memper- } \\
\text { hatikan norma- } \\
\text { norma kelestari- } \\
\text { an fungsi ruang }\end{array}$ & $\begin{array}{l}\text { Relevan: } \\
\text { Penilaian tingkat pe- } \\
\text { layanan berbagai fa- } \\
\text { silitas pendidikan un- } \\
\text { tuk semua jenjang } \\
\text { dan penentuan tindak } \\
\text { lanjut }\end{array}$ \\
\hline 3. & $\begin{array}{l}\text { Struktur umur pen- } \\
\text { duduk yang semakin } \\
\text { menua (aging) }\end{array}$ & $\begin{array}{l}\text { Semakin banyak pen- } \\
\text { duduk memasuki usia } \\
\text { kerja dan semakin } \\
\text { banyak penduduk } \\
\text { lanjut usia (Lansia) } \\
\text { serta semakin sedikit } \\
\text { penduduk usia muda } \\
\text { dan anak-anak }\end{array}$ & $\begin{array}{l}\text { Relevan: } \\
\text { Jaminan akan } \\
\text { kenyamanan } \\
\text { transportasi bagi } \\
\text { semua umur ter- } \\
\text { utama kelompok } \\
\text { Lansia }\end{array}$ & $\begin{array}{l}\text { Relevan: } \\
\text { Penyediaan ba- } \\
\text { rang \& jasa yang } \\
\text { secara spesifik } \\
\text { dibutuhkan oleh } \\
\text { para Manula pe- } \\
\text { nyediaan barang } \\
\text { dan jasa bagi } \\
\text { usia produktif }\end{array}$ & $\begin{array}{l}\text { Relevan: } \\
\text { Penyediaan akses un- } \\
\text { tuk wisata bagi ma- } \\
\text { nula baik dalam kota } \\
\text { maupun di tempat } \\
\text { lain }\end{array}$ & $\begin{array}{l}\text { Ekspansi daerah } \\
\text { pemukiman ke- } \\
\text { luar kota untuk } \\
\text { pásangan muda }\end{array}$ & $\begin{array}{l}\text { Reievan: } \\
\text { Penilaian tingkat pe- } \\
\text { layanan berbagai fa- } \\
\text { silitas pendidikan un- } \\
\text { tuk semua jenjang } \\
\text { dan penentuan tindak } \\
\text { lanjut }\end{array}$ \\
\hline
\end{tabular}




\begin{tabular}{|c|c|c|c|c|c|c|c|}
\hline \multirow{2}{*}{ No. } & \multirow{2}{*}{ TEMUAN STUDI } & \multirow{2}{*}{ INTERPRETASI } & \multicolumn{5}{|c|}{ IMPLIKASI SEKTORAL } \\
\hline & & & TRANSPORTASI & PERDAGANGAN & PARIWISATA & PERUMAHAN & PENDIDIKAN \\
\hline 4. & $\begin{array}{l}\text { Penduduk laki-laki } \\
\text { di pinggir kota sema- } \\
\text { kin dominan }\end{array}$ & $\begin{array}{l}\text { Kota tidak memberi } \\
\text { kesempatan bermu- } \\
\text { kim bagi Migran ter- } \\
\text { utama untuk mereka } \\
\text { yang miskin } \\
\end{array}$ & $\begin{array}{l}\text { Relevan: } \\
\text { Penyediaan fasi- } \\
\text { litas transportasi } \\
\text { yang murah ke } \\
\text { pusat kota }\end{array}$ & $\begin{array}{l}\text { Relevan: } \\
\text { Tuntutan akan } \\
\text { jasa-jasa cate- } \\
\text { ring yang mema- } \\
\text { dai }\end{array}$ & $\begin{array}{l}\text { Relevan: } \\
\text { Penyediaan fasilitas } \\
\text { yang terjangkau seca- } \\
\text { ra ekonomi }\end{array}$ & $\begin{array}{l}\text { Relevan: } \\
\text { Penyediaan fasi- } \\
\text { litas apartemen } \\
\text { yang sejenis }\end{array}$ & Tidak relevan \\
\hline 5. & \begin{tabular}{|l|} 
Semakin banyak \\
penduduk terdidik
\end{tabular} & $\begin{array}{l}\text { Tuntutan akan peker- } \\
\text { jaan yang bersifat } \\
\text { White coolar }\end{array}$ & $\begin{array}{l}\text { Relevan: } \\
\text { Tuntutan kenya- } \\
\text { manan }\end{array}$ & \begin{tabular}{|l|} 
Relevan: \\
Tuntutan pela- \\
yanan dan kuali- \\
tas \\
\end{tabular} & $\begin{array}{l}\text { Relevan: } \\
\text { Tuntutan variasi dan } \\
\text { kualitas objek }\end{array}$ & $\begin{array}{l}\text { Relevan: } \\
\text { Funtutan kuali- } \\
\text { tas }\end{array}$ & $\begin{array}{l}\text { Relevan: } \\
\text { Tuntuan kualitas }\end{array}$ \\
\hline $\begin{array}{l}6 . \\
.\end{array}$ & $\begin{array}{l}\text { Semakin pentingnya } \\
\text { pekerjaan sektor jasa } \\
\text { baik sebagai penye- } \\
\text { rap tenaga kerja } \\
\text { maupun penyum- } \\
\text { bang PDRB }\end{array}$ & $\begin{array}{l}\text { Industrialiasi lambat } \\
\text { dan polusi industri } \\
\text { relatif kecil ketergan- } \\
\text { tungan pada kondisi } \\
\text { global sangat besar. } \\
\text { Ketergantungan pada } \\
\text { sumberdaya alam re- } \\
\text { latif krviol tapi sa- } \\
\text { ngat tergantung SDM }\end{array}$ & $\begin{array}{l}\text { Relevan: } \\
\text { Tuntutan akan } \\
\text { fasilitas trans- } \\
\text { portasi dan ko- } \\
\text { munikasi global } \\
\text { yang memadai }\end{array}$ & $\begin{array}{l}\text { Relevan: } \\
\text { Antisipasi akan } \\
\text { linkage sektor } \\
\text { jasa di kota de- } \\
\text { ngan sektor eko- } \\
\text { nomi daerah hin- } \\
\text { terland }\end{array}$ & $\begin{array}{l}\text { Relevan: } \\
\text { Antisipasi linkage } \\
\text { yang tumbuh dari in- } \\
\text { teraksi global dan da- } \\
\text { pat meningkatkan } \\
\text { arus wisata intema- } \\
\text { sional }\end{array}$ & $\begin{array}{l}\text { Relevan: } \\
\text { Penyediaan fasi- } \\
\text { litas apartemen } \\
\text { untuk orang } \\
\text { asing yang ting- } \\
\text { gal cukup lama } \\
\text { dalam kota }\end{array}$ & $\begin{array}{l}\text { Relevan: } \\
\text { Penyediaan fasilitas } \\
\text { pendidikan yang da- } \\
\text { pat menunjang inter- } \\
\text { aksi glcbal, khusus- } \\
\text { nya dalam bidang ba- } \\
\text { hasa dan pendidikan } \\
\text { ketrampilan lainnya }\end{array}$ \\
\hline 7. & $\begin{array}{l}\text { Dikotomi sektor for- } \\
\text { mal dan informal di } \\
\text { kota menjadi sema- } \\
\text { kin nyata }\end{array}$ & $\begin{array}{l}\text { Diperlukan integrasi } \\
\text { sektor formal dan in- } \\
\text { formal dalam bentuk } \\
\text { kerjasama yang sa- } \\
\text { ling menguntungkan } \\
\text { dalam rangka meiva- } \\
\text { dahi tuntutan pelesta- } \\
\text { rian nilai-nilai tradi- } \\
\text { sional serta akomoda- } \\
\text { si nilai-nilai baru se- } \\
\text { bagai dampak } \\
\text { interaksi global }\end{array}$ & $\begin{array}{l}\text { Relevan } \\
\text { Menciptakan sis- } \\
\text { tem transportasi } \\
\text { yang membuat } \\
\text { akses kepada pe- } \\
\text { layanan sektor } \\
\text { informal yang } \\
\text { lebih baik tanpa } \\
\text { menimbulkan } \\
\text { kemacetan lalu } \\
\text { lintas }\end{array}$ & $\begin{array}{l}\text { Relevan: } \\
\text { Penciptaan sim- } \\
\text { biose mutualis- } \\
\text { me antara sektor } \\
\text { formal dan in- } \\
\text { formal kota }\end{array}$ & $\begin{array}{l}\text { Relevan: } \\
\text { Pengembangan wisa- } \\
\text { ta kota yang menem- } \\
\text { patkan sektor infor- } \\
\text { mal kota sebagai sa- } \\
\text { lah satu atraksi dari- } \\
\text { pada sebagai } \\
\text { penghambat }\end{array}$ & \begin{tabular}{|l|} 
Relevan: \\
Tuntutan peru- \\
mahan dengan \\
harga terjangkau \\
bagi pekerja sek- \\
tor informal
\end{tabular} & $\begin{array}{l}\text { Relevan: } \\
\text { Peningkatan skill } \\
\text { baik menegemen bis- } \\
\text { nis maupun skill un- } \\
\text { tuk komunikasi (ba- } \\
\text { hasa) }\end{array}$ \\
\hline
\end{tabular}

